\begin{abstract}
Research Article
(C) 2021 Chantel van Niekerk and RH Goldberg. This is an open access article licensed under the Creative Commons Attribution-NonCommercial 4.o International License (https://creativecommons.org/licenses/by-nc/4.o/)
\end{abstract}

Received: 27 February 2021 / Accepted: 15 June 2021 / Published: 8 July 2021

\title{
The Influence of Scent Marketing on Consumers' Approach and Avoidance Behaviour in the High-End Fashion Industry
}

\section{Chantel van Niekerk}

\author{
North-West University, \\ Potchefstroom, South Africa

\section{RH Goldberg} \\ North-West University, \\ Potchefstroom, South Africa
}

DOI: https://doi.org 10.36941/mjss-2021-0024

\begin{abstract}
Existing literature falls short in that it fails to directly recognise the potential that lies within scent marketing and its influence on consumers' behaviour, especially in high-end fashion stores. The study aimed to explore the influence of scent marketing on consumers' approach and avoidance behaviour in the high-end fashion industry. The study was qualitative in nature and followed an exploratory research design. A nonprobability snowball sampling method was used to recruit participants. Data was collected by means of three focus group sessions. The collected data was analysed by using the Morse and Field approach, and by making use of ATLAS.ti qualitative data analysis software. SPSS software was also used to analyse the demographic results. The results indicate that consumers' response stimuli often depend on emotional stimuli they experience, which will lead to an approach or avoidance response. Scent marketing can boost approach behaviour, if implemented correctly. Based on the results, it is recommended that retail stores, more specifically high-end fashion stores, should make use of scent marketing to attract consumers to the store, keep them browsing for longer periods, enhance purchases and make them feel comfortable. Scent can have a positive influence on consumer's evaluations, reactions and the intention to visit and revisit a store. This can result in consumers spending more time and money in the store. Furthermore, if scent marketing is implemented correctly, it could also boost brand identity and create a competitive advantage for that specific store.
\end{abstract}

Keywords: Atmospherics, Consumer behaviour, Fashion industry, High-end fashion industry, Scent marketing.

\section{Introduction}

The high-end fashion industry faces increasing competition, rising debt, and consumers who are overwhelmed with marketing messages. Scent marketing can assist companies to strengthen their identities by linking the smell of the company to their brand and effectively differentiate the brand from its competitors. Furthermore, scent can heighten perceptions towards certain goods or experiences as well as create certain emotions that will lead to an approach or avoidance response. By adopting an approach behaviour, consumers would likely want to enter a specific store and/or remain in that store for longer periods of time. Fashion is emotionally charged and it is therefore 
advantageous for fashion retailers to use scent marketing to increase consumers' involvement in the store and to form emotional bonds with consumers in a subconscious way.

The objective of the study was to explore the influence of scent marketing on consumers' approach and avoidance behaviour in the high-end fashion industry. The study was qualitative in nature and followed an exploratory research design. A non-probability snowball sampling method was used to recruit participants for the three focus group sessions. The collected data was analysed by using the Morse and Field approach, and by making use of ATLAS.ti qualitative data analysis software.

Based on the results, it is recommended that high-end fashion retail stores should make use of scent marketing to lure consumers into the store, offer them an experience in the store, as well as making them feel important and de-stressed.

\section{Problem/Opportunity Investigated}

Today, the fashion industry is experiencing intense competition, and therefore, this industry needs to explore various tactics in order to entice consumers to enter and browse around in a store (Chen \& $\mathrm{Xu}, 2017$; Yao, 2018). These industries should be aware of the benefits of scent marketing. If scent is incorporated correctly with the vision and the theme of the company, it can influence thoughts, behaviours, choices, emotions and memories (Bergland, 2015). According to Doucé and Janssens (2011), scent should be able to attract consumers' attention, influence their emotions and motivate them to enter a store.

Another issue faced by the fashion industry is the fact that consumers are overwhelmed with daily exposure to marketing messages and are starting to ignore advertisements (Emsenhuber, 2009; Value Line, 2019). Scent marketing can, however, be the exception and assist companies to strengthen their identities by linking the smell of the company to their brand and effectively differentiate the brand from its competitors (Hulten et al., 2009; Jordaan, 2019).

According to Imamovic (2016), scent and its effect on consumer buying behaviour and the decision-making process have only been recognised recently, and if this approach is implemented correctly, it could boost brand identity and create a competitive advantage for that specific store.

\section{Objective/Purpose Of The Research}

The literature above mentioned a relationship between scent marketing and consumers' behaviour. The following objective was set to achieve the goal:

- To determine the influence of scent marketing on consumers' approach and avoidance behaviour in the high-end fashion industry.

\section{Theoretical Framework/Conceptual Framework}

Atmospherics play an important role in consumer buying behaviour (Levy et al., 2012). Randhawa and Saluja (2017) define atmospherics as specific elements and physical characteristics of a retail store that is used to attract consumers. One of the atmospheric elements that is focused on during this study, that can be used to influence consumers' buying behaviour, is scent (Guillet et al., 2017; Steele \& Major, 2019). Scent marketing, also known as aroma marketing, can be defined as a promotional tool that is used to set a mood, promote products or position a brand (Meng, 2016). Krishna (2010) affirms that scent marketing creates awareness, positions, differentiates and reinforces a brand, its image, and the overall in-store experience. Scent marketing can reach people on a conscious- and subconscious level by stimulating a consumer's sense of smell, and thus affecting their behaviour (Guillet et al., 2017; Nell, 2013). The Mehrabian-Russel model indicates that environmental stimuli such as scent has an impact on consumers' emotional status, which will influence the response stimuli where consumers are likely to choose to either approach or avoid a store (Abazi \& Sohani, 
2016; Bakker et al., 2014).

\subsection{The Mehrabian-Russell model}

The Mehrabian-Russell model suggests that environmental stimuli can trigger emotional reactions that can influence consumers' behaviour (Bakker et al., 2014; Guillet et al., 2017; Kang et al., 2011).

\subsubsection{Environmental stimuli}

Environmental stimuli can be defined as those elements or characteristics that are present in a store's environment that influences consumer behaviour (De Farias et al., 2014). According to Schreuder (2016), the retail environment can create an image of a brand, arouse consumers, and motivate impulse buying behaviour. Environmental characteristics comprise sensory elements which include vision, audition, olfaction, touch and taste (Tantanatewin, 2018). According to Abazi and Sohani (2016), environmental stimuli influence consumers on a perceptive and personal level.

\subsubsection{Emotional status}

According to Vinnikova (2016), consumers' emotional reactions towards environmental stimuli will determine their behaviour such as deciding to approach or avoid a store. The Mehrabian-Russell model suggests that there are three types of emotional reactions that consumers have towards a store namely pleasure (feeling happy, satisfactory and/or content), arousal (feeling excited or calm, feeling energised or dull) and dominance (in control) (Abazi \& Sohani, 2016; Bakker, 2014; Helmefalk \& Hulten, 2017; Hung et al., 2019; Jang \& Namkung, 2009).

By considering the above, positive emotional reactions caused by environmental stimuli will likely lead to approach behaviour (Doucé \& Jannsens, 2011; Nell, 2013). Thus, The Mehrabian-Russell model indicates that consumers' emotional state in response to the environmental stimuli can cause consumers to either approach or avoid a store (Hefer, 2012).

\subsubsection{Approach or avoidance behaviour}

Consumers' response stimuli often depend on emotional stimuli they experience (Abazi \& Sohani, 2016). According to Tang and Zhangb (2018), approach behaviour is affected by the behavioural activation system (BAS); whereas avoidance behaviour is affected by the behavioural inhibition system (BIS). BAS leads to approach intentions due to positive and/or rewarding stimuli. BIS may also lead to avoidance intentions due to negative stimuli or emotions (Tang \& Zhangb, 2018). According to Kang et al. (2011), avoidance behaviour becomes negative as soon as consumers choose to avoid the store, and positive when consumers approach or enter the store. Nell (2013) states that approach behaviour is influenced by pleasant and adequate lighting, pleasant music and agreeable scents. Vinnikova (2016) affirms that human beings are instinctively wired to like and dislike certain smells and to associate certain feelings with certain smells. This leads to the general conclusion that consumers' life experiences will likely influence their reaction to certain smells (Hung et al., 2019).

Approach behaviour refers to a situation when consumers display a favourable reaction towards the store by choosing to enter the store, browse around the store and potentially buy an item in the store (Manthiou et al., 2016). Consumers would tend to choose to approach a store when a positive and pleasant emotion has been adopted through environmental stimuli (Kim et al., 2017). A pleasant scent and attractive visual merchandising are likely to lead to approach behaviour (Hefer, 2012).

Avoidance behaviour refers to when consumers would leave a store, avoid a store or not enter a store at all (Joustra, 2016; Kang et al., 2011). Consumers will rend to avoid a store when a negative emotion has been experienced through environmental stimuli. A few examples of negative experiences to expose consumers to bad or overpowering scents, overcrowding of visual merchandise 
and unpleasant music (Hefer, 2012; Parumasur \& Roberts, 2015). Thus, the approach that consumers adopt (approach or avoidance behaviour) will very likely influence their buying behaviour.

\subsection{Consumer buying behaviour}

Consumer buying behaviour can be defined as the process of searching, selecting, buying, using, evaluating and disposing of products and/or services to satisfy a need or want (Schiffman \& Wisenblit, 2019). Osadebamwen (2015) propounds that the study of consumer behaviour refers to understanding consumers' attitudes, perceptions, lifestyles, demographic characteristics, reference groups, families and cultures. Therefore, consumer behaviour involves more than merely the purchase of an item; it is the process leading to the purchase (Dumitrescu \& Vinerean, 2010; Schiffman \& Wisenblit, 2019). Prasad and Jha (2014) propound that consumers use the decisionmaking process to determine their needs and wants before making a purchase. According to Levy et al. (2012), a consumer's decisions are affected by socio-cultural- and psychological factors that contribute to the purchase- and post-purchase decision.

The consumer decision-making process comprises three stages, namely the input stage, the process stage, and the output stage (Parumasur \& Roberts, 2015; Ramya \& Ali, 2016). San and Yazdanifard (2014) propound that the input stage commences as soon as consumers recognise a need. Consumers' needs are influenced by socio-cultural factors such as culture, social class, reference groups, family, age and the economy (Durmaz \& Durmaz, 2014). Their needs are further influenced by psychological factors such as motivation, perception, learning, personality, attitudes, and emotions (Schiffman \& Wisenblit, 2019). The experience that consumers feel may give rise to a purchase and post-purchase evaluation (San \& Yazdanifard, 2014).

\subsubsection{Socio-cultural influences}

Socio-cultural factors have different effects on consumers' decisions (Durmaz \& Durmaz, 2014). These factors comprise of the lifestyle and values that describe a society (Quain, 2019; Schiffman \& Wisenblit, 2019). According to Durmaz and Duyarbakirlioglu (2011), socio-cultural factors include culture, social class, reference groups, family, age groups and the economy.

\subsubsection{Culture}

Culture can be defined as beliefs, identities, values, and customs that are fostered by consumers' experiences and that are transmitted by society and carried over from generation to generation (Masovic, 2018; Schiffman \& Wisenblit, 2019). According to Durmaz and Duyarbakirlioglu (2011), culture has a bearing on consumers' dress code, residential address, food habits, beliefs, study preferences, and ethical thinking.

\subsubsection{Social class}

A consumer's role in society together with their social status is likely to affect their buying decisions (Kozenkow, 2018). Social class can be defined as the division of a society's members into a hierarchy of classes (Schiffman \& Wisenblit, 2019). Members of one class have the same status and tend to share similar values, behaviour, and interests (Kraus et al., 2017; Srinivas, 2016). Social class is measured according to a person's occupation, income, wealth, education, status and prestige (Schiffman \& Wisenblit, 2019; Solomon et al., 2013). According to Nell (2013), social class is divided into three categories, namely low-, medium-, and upper-class consumers. 


\subsubsection{Reference Group}

Durmaz and Durmaz (2014) define a reference group as any person or group of people that influence an individual's behaviour, evaluations, aspirations and buying decisions. A reference group can have a significant influence on a consumer's attitude, feelings and behaviour, since consumers tend to follow, listen and buy that of which reference groups are buying (Levy et al., 2012; Ramya \& Ali, 2016).

\subsubsection{Family}

Family can be defined as a group of two or more people that are related by marriage, adoption or by blood (Lantos, 2011; Ramya \& Ali, 2016). According to Kozenkow (2018), family members can play the most important role in influencing consumers' decisions. Moreover, families form an environment of socialisation where consumers develop personalities, values, opinions and attitudes (Peter \& Donnelly, 2011; Rani, 2014).

\subsubsection{Age}

Age influences consumer buying behaviour, since new needs and wants develop during life-cycle changes (Cleveland et al., 2011; Ramya \& Ali, 2016). Baby Boomers are consumers aged between 50 and 70 years; Generation X includes consumers aged between 35 and 50 years; Generation Y includes consumers aged between 18 and 34 years; and Generation Z refers to teens and the younger generation (Curry, 2016). It should be taken into account that age and lifecycle impact consumers' buying behaviour, since values, activities, hobbies, and habits change throughout life (Rani, 2014). Solomon et al. (2013) propound that even though a consumer may belong to the same age group, they still differ in terms of value and cultural norms. It was found that kids prefer vanilla, creamy and fruity scents. Younger and/or teenage girls prefer a sweet smell, as well as a floral, fruity, and citrus scent. Adult women, between the ages of eighteen and twenty-four, prefer sandalwood, jasmine, lavender, peppermint, basil, citrus, and cinnamon scents (Dowthwaite, 2012; Thomas, 2015). Younger and/or teenage boys like a manly, citrus, and clean smells (Dowthwaite, 2012; Thomas, 2015). Adult men prefer the following smells: vanilla, orange, bergamot, rose, sandalwood, cinnamon, jasmine, patchouli (woody, earthy smell), clary sage (sweet, nutty flavours), musk and peppermint (Walansky \& Martin, 2019).

\subsubsection{Economy}

Economic factors indicate how much consumers spend on goods and/or services (Business Jargons, 2019). Consumer behaviour is influenced by economic factors such as personal income, family income, income expectations, savings, liquid assets, consumer credit and other economic factors (Business Jargons, 2019; Ramya \& Ali, 2016).

\subsubsection{Psychographic factors}

Psychographic factors refer to personality, motivation, perception, attitude and emotion, which are discussed below (Durmaz \& Diyarbakırlığlu, 2011).

\subsubsection{Personality}

Personality is defined as a psychological system that consists of a set of different elements that interact with each other, leading to the development of beliefs and values that influence consumers' behaviour and thoughts (Schultz \& Schultz, 2012). Every consumer has a unique personality that includes different patterns of behaviour, tendencies, characters and outlooks (Vainikka, 2015). 


\subsubsection{Motivation}

Motivation can be defined as an inner driving force that drives a consumer to take action and buy the product to satisfy a need (Durmaz \& Diyarbakırlığlu, 2011; Nell, 2013). According to Ramya and Ali (2016), a need changes into a motive when a consumer is stimulated to make a purchase, in which case a form of tension develops that will drive consumers to satisfy that need.

\subsubsection{Perception}

Perception is becoming aware of something through sensations or external influences, and how these are interpreted (Schiffman \& Wisenblit, 2019). It consists of a set of processes that occurs unconsciously throughout the day (Rani, 2014). The perception process consists of four stages, namely sensation, selection, organisation and interpretation (Schultz \& Schultz, 2012).

Sensation: Sensation is obtained through consumers' sensory receptors, which include seeing, hearing, touch, taste and smell (Lumen Learning, 2019). After obtaining the sensation, the stimuli are transmitted to the brain (Solomon et al., 2013).

Selection: Consumers' motives, impulses and incentives are influenced by selection. Selection is influenced by intense stimuli such as bright colours, lights, loud sounds, spicy flavours and strong odours (Lumen Learning, 2019). Therefore, consumers extract information that applies to their needs and/or wants (Durmaz \& Duyarbakirlioglu, 2011).

Organisation: Information is processed into meaningful patterns or similar elements (Akanksha, 2017). According to Lumen Learning (2019), the organisation of stimuli occurs during the neural process, when sensory receptors are sent to the brain to proceed through the organising process.

Interpretation: Meaning is added to each stimulus so that products are judged and value is added to products (Solomon et al., 2013). Lumen Learning (2019) adds that stimuli are affected by a consumer's beliefs, needs, values, expectations and experiences.

Selective retention: Consumers tend to forget a great deal of information but retain the information that is in line with their values, beliefs and attitudes. Some advertisements are recalled through stimuli, making it easier for consumers to recognise. These may include a brand name, packaging design, colour, logo or a scent (Durmaz \& Duyarbakirlioglu, 2011).

\subsubsection{Attitude}

Attitude can be defined as an emotional, motivational, perceptual and cognitive process that influences consumers' behaviour towards products (Asiegbu et al., 2012; Srinivas, 2016). Schiffman and Wisenblit (2019) propound that attitudes are shaped by consumers' beliefs and values, which tend to influence how consumers behave. Values are formed through cultural norms and beliefs, which in turn are influenced by family, religion and the community (Asiegbu et al., 2012; Lantos, 2011).

\subsubsection{Emotion}

Emotion is a feeling that consumers experience that influences their behaviour and/or thoughts (Soodan \& Pandey, 2016). Emotion is related to psychological phenomena which include personalities, moods, motivations and these give rise to physiological arousal, expressive behaviours and conscious experiences (Dhurup, 2014). According to Cachero and Vázquez (2016), when consumers buy goods and/or services, the end goal is to obtain emotional experiences. Furthermore, consumers' emotion affect their buying behaviour. 


\subsection{Buying intention and behaviour}

According to Tendai and Crispen (2009), consumers buy certain products, due to them being emotionally driven by feelings such as joy, love, fear, hope, and fantasy. Dhurup (2014) propounds that a store's atmosphere can play an important role in buying behaviour.

\subsubsection{Intention}

Intention can be defined as a consumer's intention to approach a store, buy an item, re-purchase an item, browse through a store or return to a store (Besra et al., 2015). Intentions are an important element for a store and should be used to understand whether the store's attributes, service and products do indeed influence consumers on a positive level (Kim, 2011). There are two types of intentions, namely browsing and buying intention (Dale, 2017).

\subsubsection{Browsing intention}

Browsing intention can be defined as the examination of a store's merchandise without an intent to buy anything within the store (Dale, 2017). According to Luo et al. (2011), it is important for retailers to get consumers to browse around in a store, since browsing can lead to unplanned buying, future buying and it can improve consumers' emotions.

\subsubsection{Buying intention}

Buying intention is defined as the willingness of a consumer to buy a product and/or service (Dale, 2017). Buying intention is influenced by the shopping process of a consumer and includes the attitude towards buying a product or making use of a service (Bhukya \& Singh, 2015). Buying intention can be influenced by price, quality, item, brand, visual merchandise and the store itself (Huang, 2012). Besra et al. (2015) found that for stores to influence buying intentions, retailers must motivate consumers through favourable store characteristics. Ambient scents can influence consumers' moods, which can have a bearing on their buying intention (Bambauer, 2012).

\subsubsection{Fashion involvement and buying behaviour}

Fashion relates to various consumers with different tastes, values and social identification (Dhurup, 2014). Fashion is about an individual's appearance that provides hedonic and utilitarian value (Dale, 2017). Fashion involvement can be described as a motivational state in which consumers find themselves which is evoked by a fashion product, and include concepts such as awareness, knowledge, interest, and reaction that a consumer displays towards fashion items (Lichtlé \& Plichon, 2014). Therefore, fashion involvement relates to fashionable clothing and items, and the degree of influence that the fashion item will have on a consumer's buying behaviour (Mishra et al., 2014).

\subsection{Fashion industry}

The fashion industry is a multi-billion dollar industry that is devoted to make and sell clothing and accessories to various groups of consumers (Dale, 2017). Dhurup (2014) propounds that fashion reflects different cultures, societies, wealth, and identities. Fashion retailers should empower consumers to express their identities through the store's clothing on offer (Dowling, 2018). The fashion industry should therefore provide opportunities for consumers to identify with the store's product offerings, for the reason that an emotional bond will develop that is likely to lead to consumer loyalty (Abazi \& Sohani, 2016). Therefore, fashion industries, especially high-end fashion industries, should satisfy consumers' needs by offering stylish, durable, comfortable, and value for 
money items (Easey, 2009).

\subsection{High-end fashion industry}

Laurea (2016) defines high-end fashion as any fashion item that is recognisable, higher-priced, of excellent quality, rarity, has a symbolic meaning and is set apart from alternative options. According to Vincent (2015), high-end fashion is the expression of uniqueness, timelessness, durability, incomparability, faithfulness, desirability, and expressing one's identity. According to Moore et al. (2010), high-end fashion brands include brands and fashion items that are exclusively designed and/or manufactured by/or for the retailer; are branded with recognisable symbols, perceived to be of superior quality, and are priced higher than the market norm. Buying high-end fashion items leads to feelings of excitement, delight, pleasure, self-evaluation, confidence, satisfaction and security (Abazi \& Sohani, 2016; Vincent, 2015). Pozharliev et al. (2015) propounds that consumers buy high-end fashion items is to project a symbol of status, showcase their physical ambitions, and the achievement at the ownership of the item.

\subsection{High-end fashion brands}

Dale (2017) propounds that high-end clothing, also known as luxury clothing, was generally associated with designer brands and Italian fashion houses. However, luxury clothing has evolved and now represents fashion items that are higher priced and exclusive (Laurea, 2016). According to Moore et al. (2010), luxury fashion brands include brands and fashion items that are exclusively designed and/or manufactured by/or for the retailer; they are branded with recognisable symbols, they are perceived to be of superior quality and are priced higher than the market norm. According to Clarke et al. (2012), luxury fashion brands assist with the development of the best fashion items for the market and play a significant role in modern fashion and in the economy.

\subsection{Consumers of high-end fashion}

According to Dale (2017), the luxury fashion industry represents the largest spending category in the luxury product category. Interestingly, Generation Y and Generation Z are at the forefront of fashion awareness (Anna, 2018). Dale (2017) states that the luxury fashion industry is constantly changing, evolving and growing. Giovannini et al. (2015) propose that "the growth of the high-end fashion industry consumption can be attributed to the changing face of the premium consumer". Generation Y, also known as Millennials, are known to be the new luxury consumers (Anna, 2018; Dale, 2017). According to Giovanninini et al. (2015) and Dale (2017), generation Y's spending has been increasing every year, and therefore the focus of luxury industries is shifting toward the younger generation, aged between 23 and 26. Generation $\mathrm{Z}$ are also consumers of high-end fashion, and are aged between 16 and 22 (Buckle, 2019). They are known to have certain expectations with regards to brandconsumer relationship, as well as value that go beyond the purchase (Anna, 2018; Dale, 2017).

According to Hung et al. (2011), consumers attach high levels of emotion to premium fashion brands and also identify themselves with the brand. Hudders and Pandelaere (2015) propound that the purchase of high-end fashion items boosts self-esteem, expresses identity, gives rise to emotions such as enjoyment and happiness. It is about expressing personal creativity, intelligence, fluidity and meaning (Atwal \& Williams, 2009; Kang et al., 2011). Another reason why consumers buy high-end fashion items is to project a symbol of status and to showcase their physical ambitions and the achievement at the ownership of the item (Pozharliev et al., 2015).

Fashion retail environments of today provide similar products and services, whereby consumers may tend to turn to a brand that appeals to their emotions and offer brand experience (Clarke et al., 2012).

High-end fashion retailers should make use of scent marketing to offer consumers an 
experience in the store, which will aid in a competitive advantage over other fashion brands (Khan, 2016). The purpose of scent marketing is to allow a scent to form part of a brand's identity, image, environment and to create lasting memories (Krishna, 2010). High-end fashion brands can also differentiate themselves from competitors by creating their unique signature scent that is memorable and distinctive (Kim \& Sullivan, 2019). According to Thomas (2015), it is very important to identify the type of scent that would match the product and correspond with consumers' needs and wants.

\section{Research Methodology}

\subsection{Research objectives}

To determine the influence of scent marketing on consumers' approach and avoidance behaviour in the high-end fashion industry.

\subsection{Sampling}

Sampling refers to the procedure of drawing a sample from a target population that will be used to represent the entire population (Babin \& Zikmund, 2016). For the purpose of this study, a nonprobability sampling method was used in the form of snowball sampling.

\section{$5 \cdot 3$ Data collection}

Data collection can be defined as the method that is used to obtain information for the specific purpose of a study (Joubert et al., 2016).

Secondary data was obtained by conducting a literature review in order to clarify and state the objectives of this study.

Primary data was collected by using a qualitative research approach. Focus groups were used to collect the data from research participants in order to obtain new insights and content-rich information. A moderator's guide was used to guide and direct the conversation of the focus group sessions.

\subsection{Data analysis}

According to Malhotra (2019), qualitative research methods result in a large amount of raw data that needs to be transcribed, refined and analysed. For the purpose of this study, data was collected by means of audio-recordings, which were transcribed by Language Matters, a professional digital audio and video transcription services provider located in Potchefstroom, South Africa. The accuracy of the transcriptions was determined by means of comparing the transcripts with the original recordings. The Morse and Field (1996) approach was used to analyse the data for this study as it is widely used in the marketing discipline and is relatively user-friendly.

\section{Results}

This section provides a detailed discussion pertaining to scent marketing's influence on consumers' behaviour and presents the research results for the two categories identified, namely approach and avoidance behaviour.

\subsection{Category 1(A): Approach}

Category $1(A)$ considers the effect of scent marketing on luring a participant into a store; the effect of scent marketing on a participant's decision to purchase an item; the effect of scent marketing on a 
participant's decision to return to the store in the future; the effect of scent marketing on the duration of a participant's stay within the store; the effect of scent marketing on a participant's decision to try on a fashion item; and a participant's decision to discuss the scent of a store with his/her reference groups.

\subsubsection{The effect of scent marketing on luring a participant into a store}

The results indicated that scent marketing is described as an attraction, since it stimulates consumers' emotions. A pleasant scent can make consumers feel that the store is of higher quality, this can enhance consumers' curiosity as to what the smell is, and this could lead them to approach the store. Furthermore, it was found that a subtle scent can have a subconscious effect on consumers. Therefore, without them realising it, scent could lead consumers to approach and/or enter a store because of an emotional reaction that took place.

It is important to remember that a scent can connect with consumers' emotions. However, before the mind can link a specific scent to a pleasant/unpleasant emotion, the scent must first be connected to a pleasant or unpleasant experience. If a consumer has a pleasant reaction to the scent, they are likely to approach the store (an attraction took place).

It was also discovered that consumers who are browsing around a shopping centre without a specific focus or time constraint could be lured into a store if they experienced a subtle and pleasant scent. Therefore, the scent could attract a consumer by eliciting an emotional response in the consumer. It was also mentioned that a pleasant scent could most likely lure a consumer in the first time, but they would only enter the store a second time if they wanted to browse or buy something in the store. However, the opposite is also true: if it is a bad smell, then consumers are likely not entering the store again.

From the results, it emerges that a number of factors play a role in terms of scent marketing's ability to attract consumers to a store and/or when it would not have an impact. Firstly, it should be taken into consideration that people have different tastes. What might smell good to one person can smell bad to someone else. Therefore, gender and age are likely to have an impact on whether consumers find a scent pleasant or unpleasant. Secondly, the mood of a consumer is likely to play a salient role. If the consumer is in a shopping mood, a pleasant scent can influence him or her to enter the store. Thirdly, if a consumer is focused on a specific task or does not have time to browse around, scent will probably not influence him or her to enter the store, except if the store stocks the product they are looking for. Fourthly, personality plays a role. The personality type of a consumer will determine whether he/she will be influenced by the scent. Also, some people are triggered by scents while others are visually stimulated. Therefore, even though a consumer may smell a pleasant scent, this may not lead him/her to enter the store, but the window display would. However, the scent would definitely enhance the shopping experience.

\subsubsection{The effect of scent marketing on a participant's decision to purchase an item}

The results indicate that when consumers encounter a pleasant scent, they tend to spend more time in the store and this could lead to a purchase. Furthermore, if the scent makes consumers feel comfortable, relaxed and de-stressed, it could also lead to a purchase, since they are likely to spend more time in the store.

The results further indicate that scent in high-end fashion stores are likely to make consumers feel like a million dollars, which will make them feel empowered. Therefore, consumers may be more eager and willing to spend money in the store.

The results of the focus group session also suggest that scent marketing may well lure consumers into a store, and that scent may enhance their mood and behaviour, which can influence their purchase decision. However, it should be taken into consideration that the entire consumer experience depends on the layout of the store, atmospherics, temperature and consumer service. All 
these aspects have an effect on how long consumers linger in the store and how much money they are likely to spend. Scent may enhance the experience, but it will not suffice on its own. Therefore, if the store smells pleasant and looks sophisticated, this could boost the possibility that the consumer will purchase an item in the store.

\subsubsection{The effect of scent marketing on a participant's re-patronage behaviour}

The results indicate that scent marketing is a subconscious way to get consumers to return to a store. If a consumer had a satisfying experience in a scent-enhanced store, he/she is more likely to return to the store and spend more money. This is because the store is connected to a pleasant scent in the mind (memory) of the consumer. Furthermore, if a consumer smells the scent of a specific store or brand, that scent is likely to make him/her recall the brand or store name.

The results further indicate that the entire consumer experience determines whether a person will return to a store or not. Scent can help to lure consumers into a store and/or seduce them to browse around in the store, but the entire experience that a consumer encountered in the store will have an influence on the overall consumer experience. If the service was bad, the consumer would be prone to remember the bad service and scent will not be able to justify it.

\subsubsection{The effect of scent marketing on the duration of a participant's stay within the store}

The results indicate that if a scent is pleasant, one is naturally going to linger longer in the store. Consumers who feel happy and relaxed are also likely to remain longer in stores, due to scent receptors in the nose that connects directly to the brain and which are responsible for linking memory and emotion. It was also found that if scent can make an individual feel calm, and once this feeling is experienced, they might stay and browse around the store for longer periods than what they would have anticipated. Furthermore, smell can also transport a person to a certain time and place, recalling a memory or feelings. If the feeling or memory is positive, consumers would tend to remain in the store. Therefore, scent is used to keep consumers in a store for longer periods of time, to enhance their moods and offer a pleasant consumer experience. However, the same is true for an unpleasant scent. If an unpleasant scent is smelled, consumers would quite likely leave the store.

It should also be taken into account that different cultures, ages and personalities have different associations with smells. This would also have an impact on the duration of a consumer's stay. Therefore, it is important that a scent matches the theme and atmospheric elements of the store. If it does not match the store, it will not match the brand and a wrong connotation can be formed of the store. Furthermore, the temperature, layout and merchandise will also play a role in terms of the duration of a consumer's stay in a store.

\subsubsection{The effect of scent marketing on a participant's decision to try on a fashion item}

The results indicate that a few participants stated yes and a few answered no, when asked whether scent would lead them to try on a fashion item. It was found that scent could perhaps lead consumers to try on fashion items, because the appropriate scent can make consumers feel calm, relaxed and destressed. If consumers feel comfortable in a store, they may feel that they have time to spend in the store, and this could lead to them trying clothes on. However, it depends on a consumer's personality and on whether he/she enjoys shopping and trying on clothes.

The results further indicate that a scent in a store or a scent on a fashion garment can bring back a memory or enhance a positive emotion, which could lead to consumers wanting to try on fashion items. Therefore, it is a subconscious feeling. 


\subsubsection{Participant's decision to discuss the scent of a store with his/her reference groups}

The results indicate that a consumer's personality has an effect on word-of-mouth and the relationship that they have with friends and/or families.

It was found that some participants often inform their friends and families when they have encountered a bad or pleasant scent. Such word-of-mouth is a means of warning family members or friends to avoid certain stores and rather choose other stores. It was further found that participants are likely to inform family or friends if they encountered a bad scent, but less likely to share their experience of a pleasant scent. Also, it was found that a bad or pleasant scent would only be mentioned to friends or family members if it arose as a topic of discussion.

The results also indicate that a consumer's personality plays a role in terms of whether or not they are likely to discuss a scent. For example, a few participants stated that they would not mention to family or friends when they have encountered a bad or pleasant scent, as it would not be worth mentioning.

Therefore, personality types and a person's relationship with friends or family play a role in terms of word-of-mouth marketing.

\subsection{Category 1(B): Avoidance}

Category 1 (B) considers the effect of scent marketing on driving a participant away from a store; the effect of scent marketing on a participant's decision not to purchase an item; and the likelihood of a participant to complain to store personnel about an unpleasant scent.

\subsubsection{Effect of scent marketing on driving a participant away from a store}

The results indicate that if a store smells repulsive, damp or if it has a general bad smell, consumers are not likely to enter the store. If it is a subtle smell, consumers may still be willing to buy the item that they were looking for, but they are not likely to browse around in the store for longer than necessary. It was also found that if there is a bad smell near or outside the store area, this would also stop consumers from entering or coming near that section of the store. Consumers also commented on public bathrooms that do not have a pleasant scent near shops. This unpleasant scent kept them away from that area in the mall; consumers are therefore likely to be unwilling to enter stores near that section of the shopping centre because of the unpleasant smell.

The results further indicate that if consumers are brand loyal, a bad scent will keep them from going to that specific store but will not stop them from buying the products. Therefore, consumers would rather shop at a different branch or even shop online. Consumers could end up changing their method of buying and not return to a specific store, because the bad smell resulted in a bad experience and memory. Another finding is that if the scent and the store's layout, temperature, season and overall theme do not match, people may well avoid a store. The season should match the scent: if the scent is cold (ice-blue or peppermint) and the store is too cold (air-conditioning), this could lead to people feeling to cold and they may end up leaving the store.

It was lastly found that some high-end consumers expect a scent to be present in a store. If there is no scent in the store, consumers can regard it as simply another store. The store will not stand out and it will not be regarded as a high-end store.

\subsubsection{Effect of scent marketing on a participant's decision not to purchase an item}

The results indicate that consumers have certain expectations that a store should live up to. If anything in the store is questionable, then consumers would be hesitant to buy from that store. Most participants indicated that an unpleasant smell will make them want to leave the store and buy the product elsewhere. It was also found that an unpleasant scent can cause a consumer to feel irritated, 
which can build up towards the merchandise. Some consumers indicated that they would not buy clothes because they would feel anxious that the garment might also smell bad. In short, the clothes may not look as "high-end" as they are supposed to look.

\subsubsection{Likelihood of a participant to complain to store personnel about an unpleasant scent}

The results indicate that it depends on a consumer's personality, the mood they are in, whether they have time to complain, and how severe the unpleasant scent is in the store. It was found that the majority of participants are likely to complain if a bad scent is present in a store. Some consumers believe in consumer feedback and they want to make personnel aware that the store is not up to its usual standard, especially in the case of a high-end fashion store. It was mentioned that if a person visited a store for the first time and there is an unpleasant scent hanging in the air, the consumer is not likely to address the situation but would most likely leave the store immediately. However, if one is a regular consumer and there is a bad smell, one would feel more at ease to mention it to the store assistant.

It was also found that a number of participants would not complain in person but would complain online or send an email to the manager. Furthermore, a few participants stated that they would not complain, but would immediately leave the store. Therefore, a consumer's personality and his/her cultural makeup have an effect with regards to feeling sufficiently at ease to complain to store personnel if an unpleasant scent is present in the store.

\section{Findings}

Scent marketing will enhance the shopping experience within a high-end fashion store, since it is appealing to inhale a pleasant scent. A pleasant scent, especially in a high-end fashion store, can make consumers feel special and important. It further indicates that the store cares about its environment and that they want to offer a delightful, relaxed and comfortable atmosphere to their consumers. Hence, high-end fashion stores should make the entire shopping experience for the client as glamorous as possible, which also indicates a sense that the store cares about its freshness and other attributes, and it wants to offer consumers a relaxing shopping environment. It was found that a blunt smell will not make the shopping experience personal, while a pleasant smell can make it personal. Furthermore, if a company has a signature scent, a consumer can form a connection with the store and/or brand. Whenever that specific scent is smelled, consumers will recall the brand and/or store.

It was found that a pleasant scent can enhance consumers' curiosity as to what the smell is and this could lead them to approach the store. Hence, a subtle scent can have a subconscious effect on consumers, without them realising it, scent could lead consumers to approach and/or enter the store. Consumers are intrigued to enter or approach a store when a classy, soothing and pleasant scent is smelled. Furthermore, consumers who are browsing around a shopping centre without a specific focus or time constraint could be lured into a store if there is a pleasant scent. However, the opposite is also true, if it is a bad smell then consumers are not likely not enter the store again. From the results it was seen that a number of factors play a role regarding scent marketing. Firstly, it should be taken into consideration that people have different tastes. Gender and age are likely to have an impact on whether consumers will find a scent pleasant or revolting. Secondly, the mood a consumer is in will play a big role. Thirdly, if a consumer is focused on a specific task or do not have time to browse around, scent will not influence the consumer to enter the store, except if the store has the product they are looking for. Fourthly, the personality type of a consumer will depend if he/she will get influenced by the scent. Some people get triggered by scent others are visually stimulated. Also, some personality types enjoy a different type of scent than others.

Therefore, when deciding on a scent, a store should decide on what gender and age they want to focus on. The scent should also make consumers feel comfortable, relaxed, de-stressed and energetic, 
which will keep them browsing the store for longer periods. High-end fashion industries should take note that it is important for the scent to match the theme and atmospheric elements (music, temperature, visuals) of the store, since this will also play a role in the attraction and duration of a consumers stay.

\section{Limitations of Existing Research}

- The study is area-specific, since the study was conducted in Sandton and in Nelspruit, due to focusing on these two locations it could limit the generalisation of the results.

- Only three focus groups were conducted. Therefore, it could limit the generalisation of the findings to the greater population.

\section{Directions for Future Research}

- The study is area-specific, therefore future research could use a wider geographic area of study.

- $\quad$ Scent marketing should also be tested in a physical high-end fashion store, to be able to get the real influence of scent marketing on consumers' behaviour.

- Future research should test a variety of scents that exhibit differences in pleasantness, arousal, evocativeness, and congruency with the product, to understand the impact and influence that scent has on consumers purchasing behaviour.

- Future research should also investigate the interaction of fragrances with other atmospheric elements, since consumers are exposed to several environmental elements at the same time

\section{Conclusions}

The primary objective of this research study is to explore the influence of scent marketing on consumers' approach and avoidance behaviour in the high-end fashion industry, since existing literature falls short in that it fails to directly recognise the potential that lies within scent marketing and its influence on consumers approach and avoidance behaviours.

As seen from the results, scent marketing can lure consumers to a store, influence their browsing times within a store, influence the decision to purchase an item; and influence the decision to return to the store in the future. However, thorough investigation should be done on the target market and it should be taken into consideration that people have different tastes, moods, and personality types.

Based on the results, it is recommended that high-end fashion retail stores make use of scent marketing to stimulate consumers approach behaviour and provide a pleasant shopping experience.

\section{Acknowledgement}

I hereby confirm that my master's dissertation has been made available online via the North-West University's institutional repository, Boloka. The name of my dissertation is 'Exploring the influence of scent marketing on consumers' buying behaviour in the high-end fashion industry'. Orcid number: orcid.org/oooo-0003-1926-880o.

\section{References}

Abazi, J. \& Sohani, A. (2016). Enticing consumers to enter fashion stores: a sensory marketing perspective. Kristianstad: University of Högskolan Kristianstad. (MBA Mini-Dissertation).

Akanksha, C. (2017). Understanding consumer behaviour. Journal of Consumer Behaviour Management, 2(265), 1-290. 
Asiegbu, I.F., Powei, D.M., \& Iruka, C. (2012). Consumer attitude: some reflections on its concept, trilogy, relationship with consumer behaviour, and marketing implications. European Journal of Business and Management, 4(13), 38-51.

Atwal, G. \& William, A. (2009). Luxury brand marketing: the experience is everything. Journal of Brand Management, 16(1), 338-346. [DOI: https://doi.org/10.1057/bm.2008.48].

Babin, B. \& Zikmund, W. (2016). Essentials of marketing research. (6th ed.). Boston, MA: Cengage.

Bakker, I., Van der Voordt, T.J.M., de Boon, J. \& Vink, P. (2014). Pleasure, arousal, dominance: Mehrabian and Russell revisited. Journal in Current Psychology, 48(1), 1-18. [DOI: https://doi.org/10.1007/s12144-014-9219-4].

Bambauer, S.S. (2012). Through which mechanisms does ambient scent affect purchase intention in retail settings? Advances in Consumer Research, 4o(1), 319-326.

Bergland, C. (2015). How does scent drive human behaviour. [Online] Available: https://www.psychologytoday.com/intl/blog/the-athletes-way/201506/how-does-scent-drivehuman-behavior.pdf (o2 June, 2019).

Besra, E., Kartini, D., \& Hasan, M. (2015). The role of retail image and consumer trust on purchase intention of private label product. International Journal of Scientific \& Technology Research, 4(5), 215-218.

Bhukya, R. \& Singh, S. (2015). The effect of perceived risk dimensions on purchase intention. American Journal of Business, 30(4), 218-230. [DOI: https://doi.org/10.1108/AJB-10-2014-0055].

Buckle, C. (2019). The luxury market in 2019: what brands should know. [Online] Available: https://blog.globalwebindex.com/chart-of-the-week/luxury-market-2019.pdf (24 October, 2019).

Business Jargon. (2019). Economic factors influencing consumer behavior. [Online] Available: https://businessjargons.com/economic-factors-influencing-consumer-behavior.pdf (12 June, 2019).

Cachero, M.S. \& Vazques, R.C. (2016). Living positive experiences in store: how it influences shopping experience value and satisfaction. Journal of Business Economics and Management, 18(3), 537553. [DOI: https://doi.org/10.3846/16111699.2017.1292311].

Chen, J. \& Xu, J. (2017). Consumer purchase decision- making process based on the traditional clothing shopping form. Journal of Fashion Technology and Textile Engineering, 5(3), 1-12. [DOI: 10.4172/2329-9568.1000156].

Clarke, D.W., Perry, P. \& Denson, H. (2012). Fashion marketing and management: an international journal. Journal of Fashion Marketing and Management, 16(4), 492-510. [DOI: https//doi.org/10.1108/13612021211265872].

Cleveland, M., Papadopoulos, N. \& Laroche, M. (2011). Identity, demographics, and consumer behaviours: international market segmentation across product categories. International Marketing Review, 28(3), 244-266. [DOI: https//doi.org/10.1108/02651331111132848].

Curry, L. (2016). What marketing content do different age groups like to consume. [Online] Available: https://www.digitaldoughnut.com/articles/2016/september/what-marketing-content-differentage-groups-like.pdf; downloaded (18 March, 2019).

Dale, H.S. (2017). Flagships and visual merchandising: effect of retail store type on shopper response to visual merchandising in the fashion clothing industry. Canterbury: University of Canterbury. (MA Thesis).

De Farias, S.A., Aguiar, E.C. \& Meloi, F.V.S. (2014). Store atmospherics and experiential marketing: a conceptual framework and research propositions for an extraordinary consumer experience. Journal of International Business Research, 7(2), 87-98. DOI: https://doi.org/10.5539/ibr.v7n2p87].

Dhurup, M. (2014). Impulsive fashion apparel consumption: the role of hedonism, fashion involvement and emotional gratification in fashion apparel impulsive buying behaviour in a developing country. Mediterranean Journal of Social Sciences, 5(8), 168-177. [DOI: https://doi.org/10.5901/mjss.2014.v5n8p168].

Doucé, L. \& Janssens, W. (2011). The presence of a pleasant ambient scent in a fashion store: the moderating role of shopping motivation and affect intensity. Environment and Behaviour, 45(2), 216-238. [DOI: https://doi.org/1 0.1177/0013916511410421]. 
Dowling, N. (2018). The scent of a deal: Eau de car showroom is becoming the way to sniff out a better relationship with consumers. [Online] Available: https://premium.goauto.com.au/thescent-of-a-deal/.pdf (2o May, 2019).

Dowthwaite, S.V. (2012). Fragrance families and personality. [Online] Available: https://wikivisually.com/wiki/Fragrance_wheel.pdf (12 June, 2019).

Dumitrescu, 1. \& Vinerean, S. (2010). International tourism market segmentation based on consumer behavior. Review of International Comparative Management, 11(5), 757-763. [DOI: https://doi.org/1434606163].

Durmaz, Y. \& Diyarbakırlığlu, I. (2011). A theoretical approach to the strength of motivation in customer behaviour. Global Journal of Human Social Science, 11(10), 37-41.

Durmaz, Y \& Durmaz, B.N. (2014). The influence of social factors on consumer buying behaviour and an empirical application in turkey. Journal of Social Science Research, 3(2), 256-263. [DOI: https://doi.org/10.24297/jssr.v2i2.3108].

Easey, M. (2009). Fashion marketing. Chichester: Wiley Blackwell.

Emsenhuber, B. (2009). Scent marketing: subliminal advertising messages. Linz: Johannes Kepler University Linz. (Honours Dissertation).

Giovannini, S., Xu, Y. \& Thomas, J. (2015). Luxury fashion consumption and generation Y consumers. Journal of Fashion Marketing and Management, 19(1), 22-40. [DOI: https://doi.org/10.1108/JFMM-o82013-0096].

Guillet, B.D., Kozak, M. \& Kucukusta, D. (2017). It's in the air: aroma marketing and affective response in the hotel world. International Journal of Hospitality and Tourism Administration, 90(1), 1-14. [DOI: https://doi.org/ 10.1080/15256480.2017.1359727].

Hefer, Y. (2012). Visual merchandising displays' effect on consumer perceptions in Tshwane: an exploratory study into the South African apparel retail industry. Tshwane: University of South Africa, Tshwane. (MBA Dissertation).

Helmefalk, M. \& Hulten, B. (2017). Multi-sensory congruent cues in designing retail store atmosphere: effects on shoppers' emotions and purchase behaviour. Journal of Retailing and Consumer Services, 38(1), 1-11. [DOI: https://doi.org/10.1016/j.jretconser.2017.04.007].

Huang, E. (2012). Online experiences and virtual goods purchase intention. Journal of Internet Research, 22(3), 252-274. [DOI: https://doi.org/10.1108/10662241211235644].

Hudders, L. \& Pandelaere, M. (2015). Is having a taste of luxury a good idea? Applied Research in Quality of Life, 10(2), 253-262. [DOI: https://doi.org/10.1007/s11482-014-9310-x].

Hulten. B., Broweus, N. \& Dijk. M. (2009). Sensory marketing. New York, NY: Palgrave Macmillan.

Hung, K., Huiling Chen, A., Peng, N., Hackley, C., Amy Tiwsakul, R. \& Chou, C. (2011). Antecedents of luxury brand purchase intention. Journal of Product and Brand Management, 20(6), 457-467. [DOI: https://doi.org/10.1108/10610421111166603].

Hung, K., Peng, N. \& Chen, A. (2019). Incorporating on-site activity involvement and sense of belonging into the Mehrabian-Russell model: the experiential value of cultural tourism destinations. Journal of Tourism Management Perspectives. 30(1), 43-52. [DOI: https://core.ac.uk/download/pdf/293865317].

Imamović, I. (2016). Aroma marketing concept and the level of awareness among Bosnia and Herzegovina population. Bursch University, Ilidza, Bosnia. ICESoS'. (21 ${ }^{\text {st }}$ International Conference on Economic and Social studies organized).

Jang, S.S. \& Namkung, Y. (2009). Perceived quality, emotions and behavioural intentions: application of an extended Mehrabian-Russell model to restaurants. Journal of Business Research, 62(1), 45146o. [DOI: https://doi-org.nwulib.nwu.ac.za/10.1016/j.jbusres.2008.01.038].

Jordaan, E. (2019). Multi-sensory selling: How retailers entice you to spend your hard-earned money. Moneyweb news. [Online] Available: https://www.moneyweb.co.za/financial-advisorviews/multi-sensory-selling-how-retailers-entice-you-to-spend-your-hard-earned-money/.pdf (02, January 2020]. 
Joubert, I., Hartell, C. \& Lombard, K. (2016). Navorsing: 'n gids vir beginner navorsers. (1st ed.). Pretoria: Van Schaik.

Joustra, L. (2016). The effect of congruence between store design and scent on consumer responses towards fashion stores. Enschede: University of Twente. (MBA Dissertation).

Kang, E., Boger, C.A., Back, K.J. \& Madera, J. (2011). The impact of sensory environments on Spagoer's emotion and behavioural intention. Houston: University Houston. (MBA Dissertation).

Kim, E.Y. (2011). Effects of web browsing motivation and retail strategy on purchase conversion behavior for apparel. Korean Journal of Human Ecology, 2o(4), 849-86o.

Kim, J., Youn, H. \& Rao, Y. (2017). Customer responses to food-related attributes in ethnic restaurants. International Journal of Hospitality and Management, 61(1), 129-139. [DOI: https://doi.org/10.1016/j.ijhm.2016.11.003].

Kim, Y.K. \& Sullivan, P. (2019). Emotional branding speaks to consumers' heart: the case of fashion brands. Journal of Fashion and Textiles, 6(2), 2-16. [DOI: https://doi.org/10.1186/s40691-0180164-y].

Khan, H. (2016). How retailers manipulate sight, smell, and sound to trigger purchase behaviour in consumers. Shopify. [Online] Available: https://www.shopify.co.za/retail/119926083-howretailers-manipulate-sight-smell-and-sound-to-trigger-purchase-behavior-in-consumers.pdf (o2, November 2019].

Kozenkow, J. (2018). Sociocultural factors that affect marketing. AZCentral. [Online] Available: https://yourbusiness.azcentral.com/sociocultural-factors-affect-marketing-4471.html (12 June, 2018].

Kraus, M.W., Park, J.W. \& Tan, J.J.X. (2017). Signs of social class: the experience of economic inequality in everyday life. Association for Psychological Science, 12(3), 422-435.

Krishna, A. (2010). Sensory marketing: research on the sensuality of products. New Yok, NY: Routledge.

Lantos, G.P. (2011). Consumer behaviour in action: real-life applications for marketing managers. New York: NY: Sharpe.

Laurea, T.D. (2016). The Riva luxury yacht: brand management as a luxury tool for strategic advantage. Padova: University of Padova. (MBA Thesis).

Levy, M., Weitz, B. \& Grewal, D. (2012). Retail management. (9th ed.). New York, NY: Hilton.

Lichtlé, M., \& Plichon, V. (2014). Emotions experienced in retail outlets: a proposed measurement scale. Journal of Marketing, 29(1), 3-24. [DOI: https://doi.org/10.1177/205157071452488o].

Lumen Learning. (2019). Boundless anatomy and physiology. [Internet: https://courses.lumenlearning.com/boundless-ap/chapter/taste-and-olfaction/.pdf (o7 July, 2019].

Luo, M.M., Chen, J., Ching, R.K.H. \& Liu, C. (2011). An examination of the effects of virtual experiential marketing on online customer intentions and loyalty. The Service Industries Journal, 31(13), 21632191. [DOI: https://doi-org.nwulib.nwu.ac.za/10.1080/o2642069.2010.503885].

Malhotra, N.K. (2019). Marketing research: an applied orientation. (7th ed.). Upper Saddle River, NJ: Pearson.

Manthiou, A., Ayadi, K., Lee, S., Chiang, L. \& Tang, L. (2016). Exploring the roles of self-concept and future memory at consumer events: the application of an extended Mehrabian-Russell model. Journal of Travel \& Tourism Marketing, 34(4), 531-543. [DOI: https://doi.org/10.108o/10548408.2016.1208786].

Masovic, A. (2018). Socio-cultural factors and their impact on the performance of multinational companies. Integrated Business Faculty, 7(1), 1-6.

Meng, H. (2016). The effects of scent on consumer behaviour. Kent: Kent State University. (MBA Dissertation).

Mishra, H.G., Sinha, P.K. \& Koul, S. (2014). Buying impulsive trait: an effective moderator for shopping emotions and perceived risk. Journal of Management Research, 14(2), 109-111.

Moore, C. M., Doherty, A. M. \& Doyle, S. A. (2010). Flagship stores as a market entry method: the perspective of luxury fashion retailing. European Journal of Marketing, 44(2), 139-161. [DOI: https://doi.org/10.1108/03090561011008646]. 
Nell, C. (2013). Exploring the influence of store atmospherics on consumers' buying behaviour in apparel retail stores: an exploratory study in Tshwane. Tshwane: Tshwane University of South Africa. (MBA Dissertation).

Osadebamwen, O.A. (2015). Consumer behaviour in product acquisition. The Marketing Review, 18(80), 335-36o. [DOI: https://doi.org/10.1362/146934715X14441363378079].

Parumasur, S.B. \& Roberts, M.L. (2015). Consumer behaviour. (3rd ed.). Cape Town: Juta.

Peter, J.P. \& Donnelly, J.H. (2011). Marketing management: knowledge and skills. (1oth ed.). New York, NY: McGraw-Hill.

Pozharliev, R., Verbeke, W.J.M.I., Van Strien, J.W. \& Bagozzi, R. P. (2015). Merely being with you increases my attention to luxury products: using EEG to understand consumers' emotional experience with luxury branded products. Journal of Marketing Research, 52(4), 546-558.

Prasad, R.K. \& Jha, M.K. (2014). Consumer buying decision models: a descriptive study. International Journal of Innovation and Applied Studies, 6(3), 335-351.

Quain, S. (2019). The effects of socio-culture on business. [Online] Available: https://smallbusiness.chron.com/effects-socioculture-business-10602.html.pdf (17 June, 2019).

Ramya, N. \& Ali, M. (2016). Factors affecting consumer buying behaviour. International Journal of Applied Research, 11(6), 76-80.

Randhawa, K. \& Saluja, R. (2017). Visual merchandising and impulse buying behaviour: is there a relationship? International Journal of Business Quantitative Economics and Applied Management Research, 4(5), 103-120.

Rani, P. (2014). Factors influencing consumer behaviour. Journal of Consumer Behaviour, 2(9), 52-61. [DOI: http://www.ijcrar.com/vol-2-9/Pinki\%2oRani.pdf].

San, Y.W. \& Yazdanifard, R. (2014). How consumer decision making process differ from youngster to older consumer generation. Journal of Research in Marketing, 2(2), 151-156. [DOI: https://doi.org/10.1.1.695.8776].

Schiffman, L.G. \& Wisenblit, J.L. (2019). Consumer behaviour. 12th ed.). Upper Saddle River, NJ: Pearson.

Schreuder, E., Erp, J., Toet, A. \& Kellen, V. (2016). Emotional responses to multisensory environmental stimuli: a conceptual framework and literature review. SAGE Open, 6(1), 1-19. [DOI: https://doi.org/10.1177/2158244016630591].

Schultz, D.P. \& Schultz, S.E. 2012. Theories of personalities. $10^{\text {th }}$ ed. Mason, Belmont: Cengage.

Solomon, M.R., Bennett, R.R. \& Previte, J. (2013). Consumer behaviour: buying, having, being. (3rd ed.). French Forest, NSW: Pearson.

Soodan, V. \& Pandey, A.C. (2016). Influence of emotions on consumer buying behaviour: a study on FMCG purchases in Uttarakhand, India. Journal of Entrepreneurship, Business and Economics, 4(2), 163-181. DOI: file:///C:/Users/chant/Downloads/48-1-146-1-10-20161107\%20(1).pdf].

Srinivas, S. (2016). Consumer behaviour. Gopalan: Gopalan Collage. (MBA Dissertation).

Steele, S. \& Major, J.S. (2019). Fashion retailing, marketing, and merchandising. [Online] Available: https://www.britannica.com/art/fashion-industry/Fashion-retailing-marketing-andmerchandising.pdf (25 May, 2019).

Tang, J. \& Zhang, P. (2018). The impact of atmospheric cues on consumers' approach and avoidance behavioral intentions in social commerce websites. Journal of Computers in Human Behaviour (Provisionally accepted). [DOI: https://doi.org/10.1016/j.chb.2018.09.038].

Tantanatewin, W. \& Inkarojrit, V. (2018). The influence of emotional response to interior colour on restaurant entry decision. International Journal of Hospital Management, 69(1), 124-131. [DOI: https://doi.org/10.1016/j.ijhm.2017.09.014].

Tendai, M. \& Crispen, C. (2009). In-store shopping environment and impulsive buying. African Journal of Marketing Management, 1(4), 102-107. [DOI: https://academicjournals.org/journal/AJMM/article-full-text-pdf/26228BD1944].

Thomas, J. (2015). Scentsational marketing in business: a study of scent atmospherics. East Tennessee: East Tennessee State University. (Undergraduate Honours Dissertation). 
Vainikka, B. (2015). Psychological factors influencing consumer behaviour. Centria: Centria University of Applied Sciences. (MBA Dissertation).

Value Line. (2020). Industry overview: apparel. [Online] Available: https://www.valueline.com/Stocks/Industries/Industry_Overview_Apparel.aspx\#.Xjak3mgzbI U.pdf; downloaded on 02 January 2020.

Vincent, B. (2015). Marketing to a high-end consumer, using the luxury strategy. [Online] Available: https://www.entrepreneur.com/article/250745.pdf, downloaded on 24 October 2019].

Vinnikova, A. (2016). A case of hedonic perception of foreigners towards Chinese culture-specific odors from scent marketing perspective. Archives of Business Research, 4(3), 21-44.

Walansky, A. \& Martin, M.D. (2019). These 20 scents are scientifically proven to turn men on. [Online] Available: https://www.yourtango.com/201074667/5-fragrances-that-make-mendrool.pdf (26 May, 20190.

Yao, R. (2018). The renaissance of physical retail: how technology and new strategies are saving stores from the retail apocalypse. [Online] Available: https://medium.com/ipg-media-lab/therenaissance-of-physical-retail-206431aadıbc.pdf (19 September, 2019]. 